\title{
Myxomycetes on Palm Trees: Species on Attalea speciosa Mart. ex Spreng
}

\author{
Marcia Percília Moura Parente ${ }^{1}$, Laise de Holanda Cavalcanti ${ }^{\mathbf{2}^{*}}$ \\ ${ }^{1}$ Centro de Ciências Biológicas e da Saúde, Universidade Estadual do Piaú, Teresina, Brasil \\ ${ }^{2}$ Centro de Ciências Biológicas, Universidade Federal de Pernambuco, Recife, Brasil \\ Email: *laise@pq.cnpq.br
}

Received October 17, 2013; revised November 17, 2013; accepted November 24, 2013

Copyright (C) 2013 Marcia Percília Moura Parente, Laise de Holanda Cavalcanti. This is an open access article distributed under the Creative Commons Attribution License, which permits unrestricted use, distribution, and reproduction in any medium, provided the original work is properly cited.

\begin{abstract}
Attalea speciosa Mart. ex Spreng (babaçu) is a palm tree of considerable economic importance in Brazil, especially in the northeast portion of the country. The myxobiota of babaçu was studied by examining living and dead trunks, leaves, inflorescences and fallen fruits on the ground during the wet season at the Teresina Park, Piauí State, Brazil. Taxonomic diversity, species diversity, frequency of occurrence, abundance and constancy of each species were determined in two areas of deciduous mixed forest. The taxonomic diversity of the myxobiota was similar, with values of 1.5 and 1.6 for the two areas. The highest frequency of occurrence value was recorded for the spathe (50\% - 54\%), followed by the petiole (18\% - 19\%) and leaf sheath (4\% - 19\%). Myxomycetes were absent on fallen fruits and rare on the leaf blade (6\%) and dead (9\%) or living (2\%) trunks. Hemitrichia serpula (Scop.) Rostaf. ex Lister, Perichaena depressa Lib., Arcyria cinerea (Bull.) Pers. and H. calyculata (Speg.) M. L. Farr were the species characterized by the highest levels of constancy, abundance and frequency. Cribraria microcarpa (Schrad.) Pers. and Stemonitopsis typhina (F. H. Wigg.) Nann.-Bremek. were occasionally present. Ceratiomyxa fruticulosa (Mull.) T. Macbr., Clastoderma debaryanum A. Blytt, Craterium aureum (Schumach.) Rostaf. and Physarum melleum (Berk. \& Broome) Massee were infrequently encountered. Other species recorded were Arcyria denudata (L.) Wettst., Cribraria cancellata (Batsch.) Nann.-Bremek., C. violacea Rex, Lycogala exiguum Morgan, Metatrichia vesparia (Batsch) Nann.-Bremek. ex G. W. Martin, Physarum bogoriense Racib., P. nucleatum Rex, P. pusillum (Berk. \& M. A. Curtis) G. Lister and Stemonitis axifera (Bull.) T. Macbr. The myxobiota of the shaded study area was characterized by a higher diversity (6.10) than the unshaded area (2.10), and the incidence of myxomycetes on the A. speciosa trees selected for study was appreciably higher (100\% and $40 \%$, respectively).
\end{abstract}

Keywords: Arecaceae; Myxobiota; Microhabitat; Substrate; Neotropics; Palm Tree

\section{Introduction}

Attalea speciosa Mart. ex Spreng. (babaçu) is a palm tree of considerable economic importance in Brazil, especially in the northeast portion of the country. In the subsistence economy of this region, the leaves of babaçu are used to make baskets, mats, fans, sieves, fences, windows, camouflage for hunting, fish traps, cages and frames for building. The trunk is used as a foundation as well as construction material for little bridges and benches. The rotten trunk is used as a fertilizer. The fruit is edible and used for the extraction of several types of raw oils as well as to complement animal food. The epi-carp

${ }^{*}$ Corresponding author. of the fruit is used to produce oil and the amid-rich endocarp is utilized as a sort of flour substitute for cassava flour in breeding or people nourishment. In addition to these uses, babaçu is also important for gardening projects $[1,2]$.

The individual plants of this species produce a stout undivided trunk that can reach a height of $20 \mathrm{~m}$. The flowers occur in paniculately branched spadices $(4-6)$ with peduncles $(1 \mathrm{~m})$ protected by a lanceolate spathe. The fruit is a drupe of variable sizes and contains $3-4$ oleaginous thin oblong seeds (nuts) with hard endocarp [3].

The range of babaçu encompasses a large portion of South America, extending from the Guianas through 
Amazonas and Mato Grosso states to Bolivia. This species of palm is also found in the states of Goiás, Tocantins, Maranhão, Ceará (Araripe zone), Piauí, Bahia, Espírito Santo and Minas Gerais [2,3].

There are large incompletely exploited babaçu forests in the states of Maranhão and Piauí. Babaçu trees occur isolated in forests or in open areas, being more frequent in degraded areas where it is a dominant pioneer species also regarded as an invasive due to its persistence [3].

The present study was undertaken to broaden our knowledge of palm trees as a substrate for the growth and development of myxomycetes by recording the incidence of these organisms on individuals of Attalea speciosa Mart. ex Spreng.

\section{Material and Methods}

The Teresina municipality $\left(05^{\circ} 05^{\prime} 12^{\prime \prime S}\right.$ and $42^{\circ} 48^{\prime} 48^{\prime \prime} \mathrm{W}$, $72 \mathrm{~m}$ elevation), is located in the mid-Parnaiba region of the northwestern portion of the Piaui State, Brazil. The climate of the region is the Aw type (Köppen classification), and January, February, March, and April are the months with the highest precipitation [4].

The Teresina Park, an environmental preservation area of deciduous mixed forest, has a total area of 160 ha, and is located on the right margin of the Poty River. To carry out the project described herein, two study areas were selected. The first of these, dominated by babaçu trees, was a shaded area with elevated air humidity; the second area, with some specimens of babaçu present, was more open (unshaded) and exposed to light, with a lower ambient humidity.

At each collection point, 10 adult and healthy individuals of babaçu were selected and observed on each of six collecting trips made during the wet season. On each occasion, the 20 palm trees were examined carefully from the base up to a height of $1.65 \mathrm{~m}$ by searching for the presence of myxomycetes sporocarps on the trunk as well as on the leaves, inflorescences and fallen fruits on the ground. Sporocarps along with a portion of the substrate upon they occurred were collected and transported to the laboratory in order to be analyzed and identified. Voucher material was deposited in the UFP Herbarium (Recife, Federal University of Pernambuco, Brazil).

The frequency of occurrence of each species was calculated for the two different environmental situations [5]. Constancy of species in each study area was calculated on the basis of the number of field trips on which the species was collected in relation to the total number of trips. This was expressed as a percentage, with those species having a value $>50 \%$ considered as constant, those with a value of $25 \%$ - $50 \%$ as accessory, and those with a value $<25 \%$ as accidental [6]. Abundance was estimated [7], with individual species considered as scarce $(<0.5 \%$ of all collections), occasional $(0.5 \%-1.5 \%)$, common
$(>1.5 \%-3 \%)$ or abundant $(>3 \%)$.

The species diversity index for the assemblage of myxomycetes studied on each area was calculated [8], with the group of sporocarps originating from the same plasmodium considered as an individual [9]. Taxonomic diversity was expressed as the ratio of species/genera (S/G) found in each study area, and the two different environments were also compared by calculating a value for coefficient of community [10].

\section{Results and Discussion}

Eighty-one specimens of myxomycetes, representing 18 species in 12 genera, were collected directly in the field from $100 \%$ of the babaçu trees selected for study in the shaded area, whereas only 17 specimens representing eight species in five genera were collected from $40 \%$ of the trees selected for study in the unshaded area. The species recorded in the entire study represented all subclasses and orders recognized for the myxomycetes [11] and were distributed among seven families and 13 genera (Tables 1-3).

Members of the families Trichiaceae, Physaraceae and Stemonitaceae were the most common, with members of the Trichiaceae especially abundant.

The values calculated for taxonomic diversity (1.5 1.6) were similar to those reported for different ecosystems located in the northeastern region of Brazil [5].

For the babaçu trees examined in the shaded area of the deciduous mixed forest, there was a higher occurrence of myxomycetes on the spathe than elsewhere, although sporocarps also could be found on the petiole, trunk (living and dead), leaf blade, raceme, and sheath. In

Table 1. Abundance and frequency of species of Ceratiomyxales, Echinosteliales and Liceales on Attalea speciosa Mart. ex Spreng. (Arecaceae) in different environments of the Teresina Park, Piauí State, Brazil. Abundant $=>7$ specimens; common $=5-7$ specimens; occasional $=2-4$ specimens; scarce = 1 specimen; 1 = shaded area; 2 = unshaded area. $\mathrm{NR}=$ no records.

\begin{tabular}{|c|c|c|c|c|}
\hline \multirow{2}{*}{ Genera/species } & \multicolumn{2}{|c|}{ Abundance } & \multicolumn{2}{|c|}{ Frequency (\%) } \\
\hline & 1 & 2 & 1 & 2 \\
\hline $\begin{array}{l}\text { Ceratiomyxa } \\
\text { C. fruticulosa } \\
\text { (Müll.) T. Macbr. }\end{array}$ & Occasional & NR & 20 & 0 \\
\hline $\begin{array}{l}\text { Clastoderma } \\
\text { C. debaryanum } \\
\text { A. Blytt }\end{array}$ & Scarce & NR & 10 & 0 \\
\hline $\begin{array}{l}\text { Cribraria } \\
\text { C. microcarpa (Schrad.) Pers. } \\
\text { C. violacea Rex } \\
\text { C. cancellata (Batsch.) } \\
\text { Nann.-Bremek. }\end{array}$ & $\begin{array}{l}\text { Occasional } \\
\text { Scarce } \\
\text { Scarce }\end{array}$ & $\begin{array}{l}\mathrm{NR} \\
\mathrm{NR} \\
\mathrm{NR}\end{array}$ & $\begin{array}{l}30 \\
10 \\
10\end{array}$ & $\begin{array}{l}0 \\
0 \\
0\end{array}$ \\
\hline $\begin{array}{l}\text { Lycogala } \\
\text { L. exiguum Morgan }\end{array}$ & Scarce & NR & 10 & 0 \\
\hline
\end{tabular}


Table 2. Abundance and frequency of species of Physarales and Stemonitales on Attalea speciosa Mart. ex Spreng. (Arecaceae) in different environments of the Teresina Park, Piauí State, Brazil. Abundant $=>7$ specimens; common $=5$ - 7 specimens; occasional $=2$ - 4 specimens; scarce $=1$ specimen; $1=$ shaded area; $2=$ unshaded area. $\mathrm{NR}=$ no records.

\begin{tabular}{|c|c|c|c|c|}
\hline \multirow{2}{*}{ Genera/species } & \multicolumn{2}{|c|}{ Abundance } & \multicolumn{2}{|c|}{ Frequency (\%) } \\
\hline & 1 & 2 & 1 & 2 \\
\hline $\begin{array}{l}\text { Craterium } \\
\text { C.aureum (Schumach) Rostaf. }\end{array}$ & Scarce & NR & 20 & 00 \\
\hline $\begin{array}{l}\text { Physarum } \\
\text { P. bogoriense Racib. } \\
\text { P. melleum (Berk. \& Broome) }\end{array}$ & $\begin{array}{l}\text { Scarce } \\
\text { Scarce }\end{array}$ & $\begin{array}{l}\text { NR } \\
\text { NR }\end{array}$ & $\begin{array}{l}10 \\
10\end{array}$ & $\begin{array}{l}00 \\
00\end{array}$ \\
\hline $\begin{array}{l}\text { Massee } \\
\text { P. nucleatum Rex } \\
\text { P. pusillum (Berk. \& M.A. } \\
\text { Curtis) G. Lister }\end{array}$ & $\begin{array}{l}\text { Scarce } \\
\text { Scarce }\end{array}$ & $\begin{array}{l}\text { NR } \\
\text { NR }\end{array}$ & $\begin{array}{l}10 \\
10\end{array}$ & $\begin{array}{l}00 \\
00\end{array}$ \\
\hline $\begin{array}{l}\text { Stemonitopsis } \\
\text { S. typhina (F. H. Wigg.) } \\
\text { Nann.-Bremek. }\end{array}$ & Common & Occasional & 40 & 20 \\
\hline $\begin{array}{l}\text { Stemonitis } \\
\text { S. axifera (Bull.) T. Macbr. }\end{array}$ & Scarce & NR & 10 & 00 \\
\hline
\end{tabular}

Table 3. Abundance and frequency of species of Trichiales on Attalea speciosa Mart. ex Spreng. (Arecaceae) in different environments of the Teresina Park, Piauí State, Brazil. Abundant $=>7$ specimens; common $=5-7$ specimens; occasional $=2$ - 4 specimens; scarce $=1$ specimen; $1=$ shaded area; 2 = unshaded area. $\mathrm{NR}=$ no records.

\begin{tabular}{|c|c|c|c|c|}
\hline \multirow{2}{*}{ Genera/species } & \multicolumn{2}{|c|}{ Abundance } & \multicolumn{2}{|c|}{ Frequency (\%) } \\
\hline & 1 & 2 & 1 & 2 \\
\hline $\begin{array}{l}\text { Arcyria } \\
\text { A. cinerea (Bull.) Pers. } \\
\text { A. denudata (L.) Wettst. }\end{array}$ & $\begin{array}{l}\text { Abundant } \\
\text { Occasional }\end{array}$ & $\begin{array}{l}\text { Occasional } \\
\text { Scarce }\end{array}$ & $\begin{array}{l}50 \\
10\end{array}$ & $\begin{array}{l}10 \\
10\end{array}$ \\
\hline $\begin{array}{l}\text { Hemitrichia } \\
\text { H. calyculata } \\
\text { (Speg.) M.L.Farr. } \\
\text { H. serpula (Scop.) Rostaf. }\end{array}$ & $\begin{array}{l}\text { Abundant } \\
\text { Abundant }\end{array}$ & Occasional & 70 & $\begin{array}{l}20 \\
30\end{array}$ \\
\hline $\begin{array}{l}\text { Perichaena } \\
\text { P. depressa Lib. } \\
\text { Metatrichia }\end{array}$ & Abundant & Occasional & 80 & 20 \\
\hline $\begin{array}{l}\text { M. vesparia (Batsch) } \\
\text { Nann.-Bremek. }\end{array}$ & NR & Scarce & 0 & 10 \\
\hline
\end{tabular}

the unshaded area, the spathe was considered to be the portion of the plant on which myxomycetes were the most frequent, followed by the petiole, sheath, blade, and raceme. Up to $60 \%$ of the species recorded on Brazilian palm trees [12] occurred on leaves, $15 \%$ on the trunk (living and dead) and only $4 \%$ on inflorescences. Myxomycetes were absent on babaçu fruits and uncommon on dead $(9 \%)$ or living (2\%) trunks. Pôrto et al. [13] reported that species of myxomycetes, including Perichaena depressa Lib. and Physarum melleum (Berk. \& Broome) Massee, were very rare on palm fruits. The same authors indicated that 10 species occurred on living leaves; 25 species ( $50 \%$ of which were members of the
Physarales) were observed on dead leaves; and 18 species in 11 genera, predominantly belonging to the Trichiales, were reported from living trunks. On the three species of palm trees (Astrocaryum vulgare Mart., Copernicia prunifera (Miller) H. E. Moore and Mauritia flexuosa L. f.) studied at the Sete Cidades National Park, Piauí State, leaves were also the plant part supporting the highest numbers of myxomycetes, followed by the petiole, sheath, and less frequently on leaflets $[5,14,15]$. These authors also mentioned records for the spathe of the inflorescence and for the raceme, but myxomycetes were absent on the trunks. On Elaeis guineensis Jacq. trees studied at the Gurjau Ecological Reserve (dense ombrophylous forest), Pernambuco State, incidence was higher on leaves, although it did not differ much from that on inflorescences [16].

When all the Brazilian palm trees analyzed for myxomycetes are considered, A. vulgare is the one which is more similar to babaçu in terms of the preferential plant parts as substrates for myxomycetes [5,12-17].

Both species richness and abundance were lower for unshaded study area than the shaded study area, and the coefficient of community calculated for the two areas was 0.54 (Tables 1-3). The most abundant species in the shaded area were Arcyria cinerea (Bull.) Pers., Hemitrichia serpula (Scop.) Rostaf. ex Lister, H. calyculata (Speg.) M. L. Farr and P. depressa, while in the unshaded area the same species were common or occasional members of the babaçu myxobiota (Table 3).

On the basis of overall constancy, five species in the Trichiaceae (A. cinerea, H. serpula, $H$. calyculata, A. denudata (L.) Wettst. and P. depressa), one species in the Cribrariaceae (Cribraria microcarpa (Schrad.) Pers.), and one species in the Stemonitaceae (Stemonitopsis typhina (F. H. Wigg.) Nann.-Bremek.) were the most characteristic members of the babaçu myxobiota (Table 4). Ceratiomyxa fruticulosa (Müll.) T. Macbr., Clastoderma debaryanum A. Blytt, Craterium aureum (Schumach) Rostaf. and P. melleum were recorded as accessory species in the babaçu myxobiota, and Lycogala exiguum Morgan, Cribraria cancellata (Batsch.) Nann.-Bremek., C. violacea Rex, Physarum pusillum (Berk. \& M. A. Curtis) G. Lister and Stemonitis axifera (Bull.) T. Macbr. were accidental members of the myxo biota (Table 4).

The frequency of species on each examined phorophyte varied between 0 and $100 \%$. Hemitrichia serpula, in addition to being one of the most constant species of the overall myxobiota, also was the most frequent member of the set of species found on the same individual in the shaded area, as well as in the unshaded one. Studying the frequency of species of the family Arecaceae as a substrate for myxomycetes, Pôrto et al. [13] also reported the frequent occurrence of members of the Trichiales, including $H$. serpula, which had the highest presence for 
Table 4. Constancy of myxomycetes occurring on Attalea speciosa Mart. ex Spreng. (Arecaceae) at the Teresina Park, Piauí, Brazil.

\begin{tabular}{cl}
\hline Constancy & \multicolumn{1}{c}{ Species } \\
\hline Constant & A. cinerea; A. denudata; C. microcarpa; \\
$\geq 50 \%$ & H. calyculata; H. serpula; P. depressa; S. typhina. \\
Accessory & C. aureum; C. debaryanum; C. fruticulosa; \\
$<50$ to $\geq 25 \%$ & P. melleum. \\
Accidental & C. cancellata; C. violacea; L. exiguum; M. vesparia; \\
$<25 \%$ & P. bogoriense; P. nucleatum; P. pusillum; S.axifera. \\
\hline
\end{tabular}

the four palm tree species (Cocos nucifera L., Acrocomia intumescens Mart., Elaeis guineensis L. and Mauritia vinifera Mart.) studied by these authors. Hemitrichia serpula also was the most frequent species in the myxobiota associated with A. vulgare, C. prunifera, M. flexuosa, and E. guineensis [5,14-16] The data obtained from babaçu confirm that this species can be considered as the most characteristic component of the palm myxobiota in the Northeast of Brazil. Hemitrichia serpula is reported on palm trees not only in Brazil but also in other countries in Asia, Africa, Central America, and New Zealand and thus can be considered as a characteristic component of the palm myxobiota worldwide [18-21].

Perichaena depressa, very frequent in the shaded area ( $80 \%$ of the examined babaçu trees), was rare in the unshaded area and recorded for just $20 \%$ of the individuals analyzed (Table 3). This species was very frequent in some members of the family Arecaceae in Brazil [13] and $P$. depressa was among the more common (with $>20$ collections) myxomycetes recorded from nikau palm, in New Zealand [21]. Mobin and Cavalcanti [15], who analyzed the myxomycete biota of $M$. flexuosa in a forest environment, recorded a high frequency (80\%) for this species, which also suggests a preference for shaded environments.

At the Teresina Park, H. calyculata was frequent (70\%) in the shaded area and rare (20\%) in the un-shaded area (Table 3). This species had already been registered in studies that analyzed the use of the palm trees as substrates for the myxomycetes and it was very frequent (80\%) on M. flexuosa and A. vulgare populations at the Sete Cidades National Park [5].

Arcyria cinerea was infrequent (50\%) in the shaded area and rare (10\%) in the unshaded area (Table 3). In other environments and on other substrates, this species is found more frequently than the records from the deciduous mixed forest examined in the present study would indicate. For example, in the study of the myxobiota of $A$. vulgare carried out in savanna vegetation, and $M$. flexuosa in forest environment [5], A. cinerea, $H$. serpula and $H$. calyculata were very frequent $(80 \%$ $100 \%)$. Considering the frequencies obtained, the other species in the family Trichiaceae were also very charac- teristic in the babaçu myxobiota, reinforcing the evidences for the affinity of this family to palm trees in general [21].

In addition to differences in the frequency of par ticular species, the two areas studied at the Teresina Park, also differ with respect to species diversity. The myxobiota of the shaded area was more diverse (6.10) than that of the unshaded area (2.10). Studying the diversity of myxomycetes on different plant parts of individuals of $C$. prunifera and A. vulgare occurring in savanna vegetation, Cavalcanti and Mobin [5] recorded similar diversity indices (4.25 and 5.05). These authors indicated that $A$. vulgare populations in savanna vegetation were characterized by a higher diversity than those sampled in a gallery forest (3.49) and a secondary forest (2.94) and when to conclude that the myxobiota is more diversified in the open vegetation that is exposed to higher degrees of luminosity and insolation. However, at the Teresina Park, the myxobiota was more diversified and the species are more abundant and frequent in the shaded area. By comparing the values obtained for A. vulgare, C. prunifera and $M$. flexuosa [5] with those obtained for individuals of babaçu palm in the deciduous mixed forest, an higher index of diversity was characteristic for A. speciosa, which suggests that it is a particularly favorable substrate for the development of myxomycetes.

\section{Acknowledgements}

The research described herein was carried out as an interinstitutional project between the Federal University of Pernambuco and the State University of Piauí, supported by Coordination for the Improvement of Higher Education Personnel (CAPES) and National Council for Scientific and Technological Development (CNPq). Laise de Holanda Cavalcanti thanks CNPq for a research productivity grant.

\section{REFERENCES}

[1] A. Anderson and P. May, "A Palmeira de Muitas Vidas," Ciência Hoje, Vol. 4, No. 20, 1985, pp. 58-64.

[2] C. Gehring, M. L. C. Zelarayan, R. B. Almeida and F. H. R. Moraes, "Allometria da Palmeira Babaçu em um Agroecossistema de Derruba-e-Queima na Periferia este da Amazônia,” Acta Amazônica, Vol. 41, No. 1, 2011, pp. 127-134.

[3] H. Lorenzi, H. M. Souza, J. T. Medeiros-Costa and N. V. B. Cerqueira, "Palmeiras do Brasil nativas e Exóticas," Plantarum, São Paulo,1996.

[4] I. M. M. F. Lima, "Revalorizando o Verde de Teresina: O Papel das Unidades Ambientais,” Cadernos de Teresina, Vol. 10, No. 24, 1996, pp. 8-13.

[5] L. H. Cavalcanti and M. Mobin, "Myxomycetes Associated to Palm Trees at the Sete Cidades National Park, Piauí State, Brazil,” Systematics and Geography of Plants, 
Vol. 74, No. 1, 2004, pp. 109-127.

[6] M. F. A. Bezerra, A. C. C. Bezerra, A. T. Nunes, C. Lado and L. H. Cavalcanti, "Mixobiota do Parque Nacional Serra de Itabaiana, SE, Brasil: Physarales,” Acta Botanica Brasilica, Vol. 22, No. 4, 2008, pp. 1044-1056. http://dx.doi.org/10.1590/S0102-33062008000400015

[7] M. Schnittler, C. Lado and S. L. Stephenson, "Rapid Biodiversity Assessment on a Tropical Myxomycete Assemblage-Maquipucuna Cloud Forest Reserve, Ecuador,” Fungal Diversity, Vol. 9, 2002, pp. 135-167.

[8] R. Margalef, “Ecologia,” Ediciones Ômega, Barcelona, 1974.

[9] U. Eliasson, "Pattern of Occurrence of Myxomycetes in a Spruce Forest in South Sweden," Holarctic Ecology, Vol. 4, No. 1, 1981, pp. 20-31.

[10] S. L. Stephenson, Y. K. Novozhilov and M. Schnittler, "Distribution and Ecology of Myxomycetes in HighLatitude Regions of the Northern Hemisphere,” Journal of Biogeography, Vol. 27, No. 3, 2001, pp. 741-754. http://dx.doi.org/10.1046/j.1365-2699.2000.00442.x

[11] M. Poulain, M. Meyer and J. Bozonnet, "Les Myxomycètes,” Fédération Mycologique et Botanique DauphinéSavoie, Sévrier, 2011.

[12] M. L. Farr, "The Myxomycetes of the IMUR Herbarium, with Special Reference to Brazilian Species,” Instituto de Micologia-Publicação 184, Recife, 1960.

[13] K. C. Pôrto, L. H. Cavalcanti and A. M. S. Correia, "Incidência de Myxomycetes em Palmae," Proceedings of the XXXIII National Congress of Botany, Maceió, 1985, pp. 181-187.

[14] M. Mobin and L. H. Cavalcanti, "Myxomycetes Sobre Buriti (Mauritia vinifera L. f., Arecaceae),” Revista da Universidade do Amazonas, Vol. 2-3, No. 1-2, 1999, pp. 43-51.

[15] M. Mobin and L. H. Cavalcanti, "Myxomycetes em Carnaubeira (Copernicia prunifera (Miller) H. E. Moore, Arecaceae)," Acta Botanica Brasilica, Vol. 14, No. 1, 2000, pp. 71-75.

[16] C. F. Silva and L. H. Cavalcanti, "Myxobiota of the Brazilian Atlantic Forest: Species on Oil Palm Tree (Elaeis guineensis, Arecaceae),” Rodriguésia, Vol. 61, No. 4, 2010, pp. 575-583.

[17] E. Hochgesand and G. Gottsberger, "Myxomycetes from the State of São Paulo, Brasil," Boletim do Instituto de Botânica, Vol. 10, 1996, pp. 1-46.

[18] I. Kalianasundaram, "Some Slime-Moulds from Southern India-XI,” Kavaka, Vol. 3, 1975, pp. 41-54.

[19] C. Lado and M. Teyssiere, "Myxomycetes from Equatorial Guinea,” Nova Hedwigia, Vol. 67, No. 3-4, 1968, pp. 421-441.

[20] M. Vilaró, “Myxomycetes de Cuba,” Revista Jardin Botánico Nacional, Vol. 12, 1991, pp. 127-131.

[21] S. L. Stephenson, "Myxomycetes Associated with Decaying Fronds of Nikau Palm (Rhopalostylis sapida) in New Zealand,” New Zealand Journal of Botany, Vol. 41, 2003, pp. 311-317. http://dx.doi.org/10.1080/0028825X.2003.9512850 